\title{
MENCERMATI PASAR MODAL: PRESPEKTIF SYARIAH
}

\author{
Qomarus Zaman \\ Jurusan Syariah STAIN Kediri \\ Jln. Sunan Ampel 7 Ngonggo Kediri \\ stainkediri@yahoo.com/ HP.081335749972
}

\begin{abstract}
Abstrak
Hereinafter about appraisal to itself Moslem law stock market concept, namely related to stock as main instrument in Moslem law stock market, hence syara ' doesn't enable stock commerce. So also publishs stock with a purpose to adds company legal capital, buys stock with a purpose to investment and commercializes it to practice on (capital gain) from price difference (margin) be activity of batil in Islam. Concerning above problems, writer proposes things following: Firstly, writer mutuallies agree to that a company required legal capital must make a move at sector that is is not is against Islam and not related to lap. Second, to do investment at one particular company, an moslem investor must choose companys which its form fulfilling Islam criterion like syirkah inan, abdan, mudharabah, wujuh and mufawadhah. Third, supporting facilities for investment developed in Moslem law stock market shall which has fulfilled Islam criterion and mengikuti/disesuaikan with form of syirkah Islam, so that later there are no even little doubt at Moslem law stock market.
\end{abstract}

Key Wor :, Pasar Modal. Saham, Obligasi, Emiten

Sektor non riil atau sektor moneter secara garis besar dapat dibagi dalam dua katagori yakni pasar uang dan pasar modal. Pasar uang adalah bertemunya permintaan dan penawaran terhadap mata uang lokal dan asing atau dengan kata lain pasar yang memperdagangkan valas, sedangkan pasar modal adalah transaksi modal antara pihak penyedia modal (investor) dengan pihak yang memerlukan modal (pengusaha) dengan menggunakan instrumen saham, obligasi, Reksa Dana dan instrumen turunannya (derivatifinstrument).

Pada masa sekarang arus uang dan modal jarang dihubungkan dengan keperluan transaksi perdagangan internasional dan kebutuhan modal untuk investasi jangka panjang. Tetapi perekonomian konvensional melihat pasar uang dan pasar modal sebagai sarana investasi jangka pendek yang bersifat spekulatif guna mendapatkan keuntungan (gain) yang cepat dan besar (Singh, 1998: 9). 
Khusus mengenai pasar modal, dunia internasional di awal abad millenium ini dikejutkan oleh skandal keuangan besar-besaran yang menimpa perusahaanperusahaan raksasa Amerika Serikat mulai dari Enron, WorldCom, AOL, Walt Disney, Vivendi Universal, Merck, Global Crossing, Xeroc, Tyco, yang melibatkan lembaga investment bank seperti CSFB, JP Morgan, dan Merrill Lycnh, dan tentu saja tidak lepas dari peranan kantor akuntan publik yang sebelumnya mengaudit perusahaan-perusahaan tersebut.

Sebagaimana diungkapkan oleh Anwar (2002), terbongkarnya skandal keuangan tersebut membuat pasar modal Amerika meradang. Harga saham di Wall Street langsung berjatuhan. Indeks Dow Jones yang sebelum terjadinya skandal berada di atas level 10.000 sempat anjlok ke titik terendah 7.702 selama lima tahun terakhir. Kehancuran harga saham di Wall Street segera menjalar ke bursa dunia lainnya. Indeks CAC Paris, DAX Frankfurt, Nikkei Tokyo, termasuk IHSG Jakarta, dan yang lain-lainnya mengalami kemerosotan tajam (Priyono, 2009).

Anjloknya harga saham di Wall Street menyebabkan jutaan orang kehilangan dana pensiun dan tabungannya. Sementara terbongkarnya skandal tersebut yang berdampak kepada kemerosotan ekonomi AS menyebabkan puluhan ribu orang kehilangan pekerjaan (Salus, 1998).

Nampaknya kita perlu mengingat kembali perjalanan pasar modal dunia untuk membuka sikap kritis kita terhadap salah satu lembaga keuangan Kapitalis tersebut. Dunia tidak akan pernah melupakan goncangan pasar modal Amerika (Oktober Hitam) pada tahun 1929 yang menyebabkan kolapsnya perekonomian dunia khususnya Amerika Serikat. Peristiwa yang dikenal sebagai The Great Depression tersebut menyebabkan kemelaratan, kelaparan dan kesengsaraan. Sejak 1929 hingga 1933 pasar modal AS kehilangan 85\% nilainya. Kemudian goncangan pasar modal selanjutnya terjadi pada bulan Oktober tahun 1987. Pada saat itu indeks harga saham di Wall Street turun 22\% dalam sehari. Di bulan yang sama pula tepatnya pada minggu terakhir Oktober 1997, harga-harga saham pasar modal utama dunia turun drastis. Penurunan harga saham tersebut berawal di Hongkong yang merambat ke Jepang, kemudian ke Eropa dan terakhir mampir di Amerika.

Meskipun lembaga yang kita bicarakan tersebut bernama pasar modal (stock market), tidak berarti segala transaksi yang terjadi di bursa efek merupakan pertemuan antara orang yang membutuhkan modal dengan para investor yang ingin menanamkan modalnya dalam suatu perusahaan yang diminatinya. Pertemuan 
antara pihak yang memerlukan modal dengan pihak yang memberikan modal hanya terjadi sekali di pasar perdana yakni pada saat IPO (Initial Public Offering). Selanjutnya para investor bebas memilih apakah memegang saham yang dibelinya sebagai suatu bentuk investasi jangka panjang atau menahannya sebentar untuk kemudian melepaskannya di pasar sekunder ketika ia melihat pergerakan harga saham menunjukkan adanya margin. Inilah tindakan umum yang secara terus menerus terjadi di pasar modal yakni keinginan untuk meraih capital gain dalam jumlah yang besar dan dalam waktu yang singkat.

Samuelson dan Nordhaus (1997) mengungkapkan kegiatan spekulatif dalam pasar modal muncul karena adanya harapan terpenuhi dengan sendirinya. Maksudnya jika seseorang membeli saham tertentu dengan harapan nilai saham akan naik, maka tindakan ini akan mendorong kenaikan harga-harga saham yang bersangkutan. Keadaan ini membuat orang semakin terdorong untuk membeli lagi dan hal ini menyebabkan kenaikan harga saham lagi.

Hanya saja keuntungan seorang investor dalam bermain saham tidak mesti diperoleh melalui capital gain dengan menjual saham pada saat harga jualnya lebih tinggi dari harga yang dibeli sebelumnya. Bisa saja investor melalui para broker melakukan goreng mengoreng saham dengan tujuan menguasai saham perusahaan tertentu yang dibeli dengan harga murah jauh di bawah harga normalnya melalui rekayasa transaksi ataupun dengan melemparkan isu-isu yang berdampak negatif terhadap perusahaan tertentu sehingga harga sahamnya jatuh. Ketika harga saham jatuh maka terjadi kepanikan di kalangan investor lain khususnya yang lebih awam, sehingga mereka melepaskan saham yang mereka pegang ke pasar agar kerugian yang lebih besar dapat dihindari.

Di balik kegiatan spekulatif tersebut pasar sangat dipengaruhi oleh faktor internal dan eksternal. Faktor internal menyangkut kinerja perusahaan yang bersangkutan yang meliputi berapa deviden yang dibagi kepada para pemegang saham, prospek usaha dan keuntungan yang akan diraih perusahaan, termasuk kinerja buruk perusahaan tersebut. Contoh faktual adalah terbongkarnya skandal keuangan WorldCom yang dalam laporan keuangannya dilaporkan untung sebesar US \$ 3,8 milyar padahal angka tersebut merupakan jumlah kerugian yang diderita perusahaan. Sentimen negatif seperti ini akan mendorong para investor melepaskan saham sehingga harga saham jatuh. Sementara faktor eksternal meliputi kebijakan 
pemerintah, kondisi makro ekonomi nasional, tingkat suku bunga perbankan, kondisi perekonomian internasional dan perkembangan bursa saham dunia.

Jadi setiap orang, badan usaha dan pemerintah dalam perekonomian Kapitalis ini pada umumnya menginginkan terus meningkatnya harga-harga saham yang dicerminkan oleh peningkatan indeks harga saham agar keuntungan demi keuntungan dapat diraih. Sementara para pelaku pasar dengan moral hazartnya melakukan rekayasa apapun untuk mendapatkan keuntungan yang tentu saja merugikan pihak lain. Inilah gambaran ekonomi angan-angan yang terjadi dalam lembaga ekonomi Kapitalis tersebut. Sebagaimana yang dikatakan ilmuwan Isaac Newton (sebagai korban angan-angan keuntungan transaksi saham) yang dikutip Alan Woods dan Ted Grant: "Saya bisa menghitung gerakan benda-benda di langit, namun saya tidak mampu memperhitungkan kegilaan orang-orang"' (Woods, 2003).

Di tengah kemerosotan, skandal dan resiko yang menimpa pasar modal konvensional tersebut, kini dunia mulai melirik Islam sebagai alternatif. Didahului oleh pendirian bank syariah dan lembaga asuransi syariah di negeri-negeri Islam termasuk di Barat sendiri, kini upaya untuk menerapkan dan mensosialisaikan pasar modal syariah semakin gencar.

Sebagaimana dilaporkan Republika (2003), pada 14 Maret 2003 yang lalu pemerintah yang diwakili Menteri Keuangan Boediono, Bapepam dan MUI secara resmi meluncurkan pasar modal syariah. Sebelumnya pada tahun 2000 PT Bursa Efek Jakarta (BEJ) bekerjasama dengan PT Danareksa Investment Management (DIM) telah meluncurkan Jakarta Islamic Index, sementara itu Reksa Dana Syariah pertama sudah ada pada tahun 1997, serta diterbitkannya Obligasi Syariah Mudharabah Indosat pada tahun 2002. Yang lebih menarik lagi, di pusat keuangan Kapitalis dunia Wall Street, Dow Jones pada Februari 1999 telah meluncurkan Dow Jones Islamic Market Indexes (DJIMI). Perkembangan tersebut disambut gembira oleh banyak pihak.

Melihat hal tersebut, penulis menilai bahwa merupakan suatu hal yang menggembirakan ketika dunia khususnya negeri-negeri Islam mulai melirik Islam sebagai sistem alternatif. Akan tetapi kita harus bersikap kritis atas konsep baru yang ditawarkan tersebut. Yakni apakah pasar modal syariah tersebut secara prinsip tidak jauh berbeda dengan pasar modal konvensional? Atau apakah konsep dan aplikasi pasar modal syariah sudah sesuai dengan syariat Islam? 


\section{PASAR MODAL}

Pasar modal identik dengan sebuah tempat di mana modal diperdagangkan antara pihak yang memiliki kelebihan modal (investor) dengan orang yang membutuhkan modal (issuer) untuk mengembangkan investasi (Anoraga, 2001). Dalam Undang-Undang Pasar Modal No. 8 tahun 1995, pasar modal didefinisikan sebagai kegiatan yang bersangkutan dengan Penawaran Umum dan perdagangan Efek, Perusahaan Publik yang berkaitan dengan Efek yang diterbitkannya, serta lembaga dan profesi yang berkaitan dengan Efek.

Adapun pihak-pihak yang terlibat dalam pasar modal adalah:

\section{Emiten}

Emiten adalah badan usaha (perseroan terbatas) yang menerbitkan saham untuk menambah modal atau menerbitkan obligasi untuk mendapatkan pinjaman kepada para investor di Bursa Efek.

2. Perantara Emisi, yang meliputi:

a. Penjamin Emisi

Penjamin emisi adalah perantara yang menjamin penjualan emisi, sehingga apabila dari emisi wajib membeli (setidak-tidaknya sementara waktu sebelum laku) agar kebutuhan dana yang diperlukan emiten terpenuhi sesuai rencana.

b. Akuntan Publik

Akuntan publik berfungsi untuk memeriksa kondisi keuangan emiten dan memberikan pendapat apakah laporan keuangan yang telah dikeluarkan emiten wajar a tau tidak.

\section{c. Perusahaan Penilai}

Perusahaan Penilai berfungsi untuk memberikan penilaian terhadap emiten, apakah nilai aktiva emiten sudah wajar atau tidak.

\section{Badan Pelaksana Pasar Modal}

Badan Pelaksana Pasar Modal adalah badan yang mengatur dan mengawasi jalannya pasar modal, termasuk mencoret emiten (delisting) dari lantai bursa, memberikan sanksi kepada pihak-pihak yang melanggar peraturan pasar modal. Di Indonesia Badan Pelaksana Pasar Modal adalah Bapepam (Badan Pengawas dan Pelaksana Pasar Modal). 


\section{Bursa Efek}

Bursa Efek merupakan tempat diselenggarakannya kegiatan perdagangan efek pasar modal yang didirikan oleh suatu badan usaha. Di Indonesia terdapat dua Bursa Efek, yaitu Bursa Efek Jakarta (BEJ) yang dikelola PT Bursa Efek Jakarta dan Bursa Efek Surabaya (BES) yang dikelola oleh PT Bursa Efek Surabaya.

\section{Perantara Perdagangan Efek}

Efek yang diperdagangkan dalam bursa hanya boleh ditransaksikan melaui perantara, yaitu makelar (broker) dan komisioner.

a. Makelar adalah pihak yang melakukan pembelian dan penjualan efek untuk kepentingan orang lain dengan memperoleh imbalan.

b. Komisioner adalah pihak yang melakukan pembelian dan penjualan efek untuk kepentingan sendiri atau orang lain dengan memperoleh imbalan.

\section{Investor}

Investor adalah pihak yang menanamkan modalnya dalam bentuk efek di bursa dengan membeli atau menjual kembali efek tersebut. Di dalam pasar modal proses perdagangan efek (saham dan obligasi) melalui tahapan pasar perdana kemudian pasar sekunder. Pasar perdana adalah penjualan perdana saham dan obligasi oleh emiten kepada para investor. Kedua pihak yang saling memerlukan ini tidak bertemu secara dalam bursa tetapi melalui pihak perantara. Dari penjualan saham dan efek di pasar perdana ini, pihak emiten memperoleh dana yang dibutuhkan untuk mengembangkan usahanya.

Sedangkan pasar sekunder adalah pasar yang terjadi sesaat atau setelah pasar perdana. Maksudnya setelah saham dan obligasi yang dibeli investor dari emiten, maka investor tersebut menjual kembali saham dan obligasi kepada investor lainnya, baik dengan tujuan mengambil untung dari kenaikan harga (capital gain) maupun untuk menghindari kerugian (capital loss). Perdagangan di pasar sekunder inilah yang secara reguler terjadi di bursa efek setiap harinya (Jakarta Stock Exchange, 2009).

\section{PERBEDAAN PASAR MODAL SYARIAH DENGAN KONVENSIONAL}

Ada dua hal utama dalam pasar modal syariah yaitu indeks Islam dan pasar modal syariah itu sendiri. Indeks Islam menunjukkan pergerakan harga-harga 
saham dari emiten yang dikatagorikan sesuai syariah, sedangkan pasar modal syariah merupakan institusi pasar modal sebagaimana lazimnya yang diterapkan berdasarkan prinsip-prinsip syariah.

a. Indeks saham konvensional dan Indeks saham Islam

Indeks Islam tidak hanya dapat dikeluarkan oleh pasar modal syariah saja tetapi juga oleh pasar modal konvensional. Bahkan sebelum berdirinya institusi pasar modal syariah di suatu negeri, bursa efek setempat yang tentu saja berbasis konvensional terlebih dahulu mengeluarkan indeks Islam. Di Bursa Efek Jakarta misalnya, PT Bursa Efek Jakarta (BEJ) bekerja sama dengan PT Danareksa Invesment Management (DIM) meluncurkan Jakarta Islamic Index (JII) sebelum pasar modal syariah sendiri diresmikan.

Adapun tujuan diadakannya indeks Islam sebagaimana Jakarta Islamic Index yang melibatkan 30 saham terpilih, yaitu sebagai tolak ukur (benchmark) untuk mengukur kinerja investasi pada saham yang berbasis syariah dan meningkatkan kepercayaan para investor untuk mengembangkan investasi dalam ekuiti secara syariah, atau untuk memberikan kesempatan kepada investor yang ingin melakukan investasi sesuai dengan prinsip-prinsip syariah.

Perbedaan mendasar antara indeks konvensional dengan indeks Islam adalah indeks konvensional memasukkan seluruh saham yang tercatat di bursa dengan mengabaikan aspek halal haram, yang penting saham emiten yang terdaftar (listing) sudah sesuai aturan yang berlaku (legal). Akibatnya bukanlah suatu persoalan jika ada emiten yang menjual sahamnya di bursa bergerak di sektor usaha yang bertentangan dengan Islam atau yang memiliki sifat merusak kehidupan masyarakat. Misalnya pada awal tahun 2003 yang lalu, di Australia ada rumah bordir (pelacuran) yang masuk ke bursa efek setempat.

Secara lebih rinci Dow Jones dalam web site-nya (2009) membuat kriteria saham yang tidak boleh dimasukkan ke dalam perhitungan Indeks Pasar Islam (DJ Islamic Market Indexes), yaitu perusahaan yang bergerak dalam produksi:

1. Alkohol (minuman keras).

2. Babi dan yang terkait dengannya.

3. Jasa keuangan konvensional / Kapitalis, seperti bank dan asuransi.

4. Industri hiburan, seperti hotel, kasino dan perjudian, bioskop, media porno dan industri musik. 
Dow Jones juga mengemukakan pendapat para sarjana Islam agar tidak berinvestasi pada perusahaan yang terkait dengan tembakau dan rokok serta industri senjata pemusnah massal.

Sementara itu, FTSE dalam papernya yang berjudul Ground Rules for the Management of the FTSE Global Islamic Index Series mengemukakan bahwa saham perusahaan yang dimasukkan ke dalam indeks Islam tidak boleh bergerak dalam bidang:

1. Perbankan dan bisnis keuangan lainnya yang terkait dengan bunga (interest).

2. Alkohol.

3. Rokok.

4. Judi.

5. Pabrik senjata.

6. Asuransi jiwa.

7. Peternakan babi, pengepakan dan pengolahan atau hal-hal lainnya yang terkait dengan babi.

8. Sektor / perusahaan yang siknifikan dipengaruhi oleh hal-hal yang disebutkan di atas.

9. Perusahaan yang memiliki beban utang ribawi dengan persentasinya terhadap aset perusahaan melebihi batas-batas yang diijinkan hukum Islam.

Pada Bursa Efek Jakarta (BEJ), menurut Adiwarman (2003) dari 333 emiten yang tercatat 236 saham di antaranya tergolong sesuai syariah. Sedangkan sisanya 59 saham tergolong "haram" atau tidak sesuai dengan prinsip syariah, seperti saham perbankan, minuman keras dan rokok. Sisanya 34 saham tergolong subhat seperti saham industri perhotelan dan empat saham mudharat.

Dari uraian di atas dapat ditarik garis pemisah antara indeks Islam dan indeks konvensional. Pertama, jika indeks Islam dikeluarkan oleh suatu institusi yang bernaung dalam pasar modal konvensional, maka perhitungan indeks tersebut berdasarkan kepada saham-saham yang digolongkan memenuhi kriteria-kriteria syariah sedangkan indeks konvensional memasukkan semua saham yang terdaftar dalam bursa efek tersebut. Kedua, jika indeks Islam dikeluarkan oleh institusi pasar modal syariah, maka indeks tersebut didasarkan pada seluruh saham yang terdaftar di dalam pasar modal syariah yang sebelumnya sudah diseleksi oleh pengelola. 


\section{b. Instrumen}

Dalam pasar modal konvensional instrumen yang diperdagangkan adalah surat-surat berharga (securities) seperti saham, obligasi, dan instrumen turunannya (derivatif) opsi, right, waran, dan Reksa Dana.

Saham merupakan surat tanda penyertaan atau pemilikan seseorang atau badan terhadap perusahaan yang menerbitkan saham tersebut, sedangkan obligasi merupakan bukti pengakuan utang dari perusahaan kepada para pemegang obligasi yang bersangkutan.

Opsi merupakan produk turunan (derivatif) dari efek (saham dan obligasi). Robert Angg (1997) sebagaimana dikutip Anoraga dan Pakarti (2001) mendefinisikan opsi sebagai produk efek yang akan memberikan hak kepada pemegangnya (pembeli) untuk membeli atau menjual sejumlah tertentu dari aset finansial tertentu, pada harga tertentu, dan dalam jangka waktu tertentu.

Adapun right adalah efek yang memberikan hak kepada pemegang saham lama untuk membeli saham baru yang akan dikeluarkan emiten pada proporsi dan harga tertentu.

Warant merupakan turunan dari saham biasa yang bersifat jangka panjang dan memberikan hak kepada para pemegangnya untuk membeli saham atas nama dengan harga tertentu.

Sedangkan Reksa Dana (mutual fund) adalah perusahaan investasi yang mengelola investasi saham, obligasi, dan lain-lainnya, dengan menerbitkan surat berharga tersendiri yang ditujukan kepada para investor, sehingga para investor tersebut tidak perlu lagi melakukan investasi langsung terhadap berbagai surat berharga yang diperdagangkan di bursa efek tetapi cukup membeli surat berharga yang diterbitkan Reksa Dana tersebut (Noer, 2003).

Dalam pasar modal syariah, instrumen yang diperdagangkan adalah saham, obligasi syariah dan Reksa Dana Syariah, sedangkan opsi, waran dan right tidak termasuk instrumen yang dibolehkan.

Adapun yang dimaksud saham dalam pasar modal syariah sama dengan saham dalam pasar modal konvensional. Hanya bedanya saham yang diperdagangkan dalam pasar modal syariah harus datang dari emiten yang 
memenuhi kriteria-kriteria syariah sebagaimana yang penulis sebutkan dalam pembahasan indeks Islam.

Sementara obligasi syariah berbeda dengan obligasi konvensional. Obligasi konvensional merupakan suatu jenis produk keuangan yang tidak dibenarkan dalam Islam karena menggunakan bunga sebagai daya tariknya. Menurut Muhammad alAmin, intrumen obligasi syariah dapat diterbitkan dengan menggunakan prinsip mudharabah, musyarakah, ijarah, istisnaâ, salam, dan murabahah sehingga dari prinsip ini nama obligasi syariah tergantung pada prinsip yang mana yang digunakan emiten.

Sebagaimana dilaporkan Republika (2003), di Indonesia penerbitan obligasi syariah ini dipelapori oleh Indosat dengan menerbitkan Obligasi Syariah Mudharabah Indosat senilai Rp 100 milyar pada Oktober 2002 yang lalu. Obligasi ini mengalami oversubribed dua kali lipat sehingga Indosat menambah jumlah obligasi yang ditawarkan menjadi Rp 175 milyar. Langkah Indosat ini diikuti Bank Muamalat dan Bank Syariah Mandiri (BSM) pada tahun ini.

Dalam konsep Obligasi Syariah Mudharabah, emiten menerbitkan surat berharga jangka panjang untuk ditawarkan kepada para investor dan berkewajiban membayar pendapatan berupa bagi hasil atau margin fee serta pokok utang obligasi pada waktu jatuh tempo kepada para pemegang obligasi tersebut. Dalam hal ini pihak emiten berfungsi sebagai mudharib sedangkan investor pemegang obligasi sebagai shahibul mal. Sementara emiten yang menerbitkan obligasi syariah harus memenuhi persyaratan seperti persyaratan emiten yang masuk dalam kriteria indeks Islam.

Instrumen ketiga yang diperdagangkan dalam pasar modal syariah adalah Reksa Dana Syariah. Reksa Dana Syariah merupakan sarana investasi campuran yang menggabungkan saham dan obligasi syariah dalam satu produk yang dikelola oleh manajer investasi. Manajer investasi menawarkan Reksa Dana Syariah kepada para investor yang berminat, sementara dana yang diperoleh dari investor tersebut dikelola oleh manajer investasi untuk ditanamkan dalam saham atau obligasi syariah yang dinilai menguntungkan.

Sementara itu perkembangan Reksa Dana Syariah di Indonesia masih lambat. Pada tahun 2002 lalu dana masyarakat yang terhimpun dalam Reksa Dana baru mencapai Rp 40 milyar atau sekitar 0,1\% dari total Reksa Dana.

Sedangkan Reksa Dana yang ada saat ini baru Danareksa Syariah dan Danareksa Syariah Berimbang yang dikelola Danareksa, Reksa Dana PNM Syariah 
yang dikelola Permodalan Nasional Madani (PNM), Rifan Syariah yang dikelola Rifan Asset Management (RAM) dan Reksa Dana Batasa Syariah yang baru diluncurkan PT Batasa Capital pada tahun ini.

\section{c. Mekanisme transaksi}

Dalam konteks pasar modal syariah, menurut Alhabshi (1993), idealnya pasar modal syariah itu tidak mengandung transaksi ribawi, transaksi yang meragukan (gharar), dan saham perusahaan yang bergerak pada bidang yang diharamkan. Pasar modal syariah harus bebas dari transaksi yang tidak beretika dan amoral, seperti manipulasi pasar, transaksi yang memanfaatkan orang dalam (insider trading), menjual saham yang belum dimiliki dan membelinya belakangan (short selling).

Sementara itu Obaidullah (2001) mengemukakan etika di pasar modal syariah, yaitu setiap orang bebas melakukan akad (freedom contract) selama masih sesuai syariah, bersih dari unsur riba (freedom from al-riba), gharar (excessive uncertainty), al-qimar/judi (gambling), al-maysir (unearned income), manipulasi dan kontrol harga (price control and manipulation), dlarar (detriment) dan tidak merugikan kepentingan publik (unrestricted public interest), juga harga terbentuk secara fair (entitlement to transact at fair price) dan terdapat informasi yang akurat, cukup dan apa adanya (entitlement to equal, adequate, and accurate infromation).

Inti dari apa yang disebutkan oleh Alhabshi dan Obaidullah tersebut (2001) adalah pasar modal syariah harus membuang jauh-jauh setiap transaksi yang berlandaskan spekulasi. Inilah bedanya dengan pasar modal konvensional yang meletakkan spekulasi saham sebagai cara untuk mendapatkan keuntungan. Meskipun dalam kasus-kasus tertentu seperti insider trading dan manipulasi pasar dengan membuat laporan keuangan palsu dilarang dalam pasar modal konvensional.

Irfan Syauqi (2003) menjelaskan perihal spekulasi ini, pertama, spekulasi hakikatnya bukanlah kegiatan investasi, kedua, spekulasi menyebabkan peningkatan pendapatan bagi sekelompok masyarakat tanpa memberikan konstribusi apapun baik yang bersifat positif maupun produktif, ketiga, spekulasi merupakan sumber penyebab krisis keuangan, dan keempat, spekulasi datang dari mental ingin cepat kaya.

Dalam mekanisme transaksi produk pasar modal syariah, Irfan Syauqi (2003) mengemukakan wacana bahwa transaksi pembelian dan penjualan saham tidak 
boleh dilakukan secara langsung. Dalam pasar modal konvensional investor dapat membeli atau menjual saham secara langsung dengan menggunakan jasa broker atau pialang. Keadaan ini memungkinkan bagi para spekulan untuk mempermainkan harga. Akibatnya perubahan harga saham ditentukan oleh kekuatan pasar bukan karena nilai intrinsik saham itu sendiri. Menurut Irfan Syauqi hal ini dilarang dalam Islam. Untuk itu dalam proses perdagangan saham, emiten memberikan otoritas kepada agen di lantai bursa, selanjutnya agen tersebut bertugas untuk mempertemukan emiten dengan calon investor tetapi bukan untuk menjual dan membeli saham secara langsung. Kemudian saham tersebut dijual/dibeli karena sahamnya memang tersedia dan berdasarkan prinsip first come - first served.

Perkembangan harga saham dalam pasar modal konvensional sudah lepas dari nilai instrinsiknya yang dipicu oleh transaksi spekulatif, juga muncul dari keinginan para pelaku pada umumnya agar harga saham terus meningkat sebagaimana yang dikemukakan oleh Samuelson dan Nordhaus dalam bagian pendahuluan paper ini.

Kenaikkan harga saham bukan didorong oleh bertambahnya keuntungan perusahaan dan jumlah deviden yang dibagikan, tetapi didorong oleh harapan dan impian pemburu saham terutama dari kalangan yang paling awam. Kondisi seperti ini merupakan sasaran empuk bagi para spekulan yang sangat jeli dalam menganalisis perkembangan pasar.

Juga merupakan hal yang lumrah bagi pelaku di pasar modal konvensional untuk membeli sejumlah saham dalam satu hari (tentunya dengan perkiraan harga saham terus menanjak (bull market) misalnya dengan total nilai Rp 100 juta dengan modal di tangan hanya Rp 10 juta di mana kekurangannya Rp 90 juta (90\%) dipinjam dari bank. Ia berani menanggung beban bunga karena beranggapan mungkin dalam satu hari atau beberapa hari berikutnya, atau satu minggu hingga satu bulan kemudian harga saham terus meningkat.

Dalam perdagangan obligasi syariah, menurut Muhammad Gunawan (2002) tidak boleh diterapkan harga diskon atau harga premium yang lazim dilakukan pada obligasi konvensional. Prinsip transaksi obligasi syariah adalah al-hawalah (transfer service atau pengalihan piutang dengan tanggungan bagi hasil), sehingga jual beli obligasi syariah hanya boleh pada harga nominal pelunasan jatuh tempo obligasi 
Sedangkan untuk perdagangan Reksa Dana Syariah, manajer investasi menawarkan kepada pembeli Reksa Dana Syariah yang bersifat jangka pendek di pasar uang dan Reksa Dana Syariah jangka panjang di pasar saham. Misalnya Danareksa Syariah mengalokasikan 80\% investasinya di saham dan 20\% di pasar uang atau surat utang. Keuntungan yang diperoleh investor dalam Reksa Dana Syariah ini sangat bergantung pada bagaimana manajer investasi menginvestasikan dana yang dikelolanya.

\section{KONSEP SYARIAH DALAM PASAR MODAL SYARIAH}

Untuk menilai pasar modal syariah, menurut penulis adalah sangat penting bagi kita menelaah institusi (badan usaha) yang bernama perseroan terbatas (PT) karena perseroan terbataslah yang menerbitkan saham dan sebagai emiten mencatatkannya di bursa efek untuk diperdagangkan, juga saham merupakan instrumen yang paling utama diperdagangkan dalam pasar modal.

Meskipun dalam konsep pasar modal syariah disebutkan bahwa saham yang diperdagangkan harus berasal dari perusahaan yang bergerak dalam sektor yang memenuhi kriteria syariah dan terbebas dari unsur riba, serta transaksi saham dilakukan dengan menghindarkan berbagai praktik spekulasi, hal itu tetap tidak membedakan pasar modal syariah dengan pasar modal konvensional secara menyeluruh.

Bagaimana kegiatan bisnis dilakukan dan bagaimana bentuk perseroan adalah dua masalah yang berbeda. Penulis sepakat bahwa suatu badan usaha harus bergerak pada sektor-sektor dan mekanisme transaksi yang dibolehkan syariat Islam. Hanya saja penulis tidak sepakat dengan bentuk badan usaha berupa perseroan terbatas, apalagi permasalahan ini tidak disentuh dalam perkembangan wacana pasar modal syariah karena memang instrumen utama yang diperdagangkan di pasar modal syariah adalah saham sedangkan penerbitan saham itu sendiri merupakan metode manajemen suatu perseroan terbatas untuk memperoleh pendanaan atas kegiatan usahanya.

\section{SYARAT PERSEROAN (SYIRKAH) DALAM ISLAM}

Perseroan (syirkah) dari segi bahasa memiliki makna penggabungan dua bagian atau lebih sehingga tidak bisa dibedakan lagi satu bagian dengan bagian yang lain. Sedangkan menurut syara', an-Nabhani (2000) mengungkapkan bahwa 
perseroan adalah transaksi antara dua orang atau lebih yang bersepakat untuk melakukan kerja yang bersifat finansial dengan tujuan mencari keuntungan.

Transaksi perseroan tersebut mengharuskan adanya ijab dan qabul sebagaimana yang dilakukan dalam transaksi lainnya di mana salah satu di antara mereka mengajak yang lain untuk mengadakan kerjasama dalam suatu masalah, sehingga kesepakatan tersebut belum cukup hanya dengan kesepakatan untuk melakukan perseroan saja atau memberikan modal untuk perseroan saja, tetapi harus mengandung makna bekerjasama dalam suatu urusan.

Adapun mengenai syarat sah dan tidaknya transaksi perseroan sangat tergantung pada sesuatu yang ditransaksikan, yaitu harus sesuatu hal yang bisa dikelola. Sesuatu yang bisa dikelola ini haruslah sesuatu yang bisa diwakilkan sehingga mengikat semua pihak yang melakukan perseroan.

Dalam Islam perseroan yang dibolehkan dapat diklasifikasikan menjadi lima jenis, yaitu perseroan inan, abdan, mudharabah, wujuh, dan mufawadhah.

\section{Tanggung Jawab Dalam Perseroan Terbatas}

Sementara itu kebatilan perseroan terbatas dalam ekonomi konvensional terletak pada tanggung jawab terbatas. Jika perusahaan rugi atau bangkrut para kreditur dan pemilik hak lainnya tidak dapat menuntut para persero perusahaan sedikitpun, berapapun kewajiban perusahaan terhadap mereka. Mereka hanya bisa menuntut atas haknya sebatas aset perusahaan yang tersisa. Dengan demikian sistem perseroan ini merupakan suatu perlindungan sistematis bagi para pemilik modal dan pengelola perusahaan.

Masih menurut an-Nabhani (2000), sistem perseroan dengan tanggung jawab terbatas bertentangan dengan hukum syara' yang menuntut ditunaikannya seluruh kewajiban mereka terhadap pihak lain di dunia ini, sebagaimana hadits Nabi SAW yang diriwayatkan oleh Imam Bukhari dari Abu Hurairah:

“Siapa saja yang mengambil harta orang dan bermaksud untuk melunasinya, maka Allah akan menolongnya untuk melunasinya. Dan siapa saja yang mengambil harta orang dan bermaksud merusaknya, maka Allah akan merusak orang itu."

Juga dalam hadits yang lain: 
"Sungguh hak-hak itu pasti akan ditunaikan kepada para pemiliknya pada hari kiamat nanti, hingga seekor domba betina tak bertanduk akan mendapat kesempatan membalas karena pernah ditanduk oleh domba betina bertanduk." (HR. Imam Ahmad dari Abu Hurairah).

"Perbuatan orang kaya menunda-nunda pembayaran utangnya adalah suatu kezhaliman." (HR. Imam Bukhari dari Abu Hurairah).

"Sebaik-baik orang di antara kalian, adalah yang paling baik dalam penunaian hak (pembayaran utang, dan lain-lain). (HR. Imam Bukhari).

\section{Perseroan Terbatas: Prespektif Syariah}

Kebatilan perseroan terbatas yang lain adalah bahwa pihak-pihak yang ikut serta dalam perseroan terbatas meleburkan dirinya dengan jalan pembagian komposisi kepemilikan saham oleh para pendiri pada saat perseroan terbatas tersebut pertama kali didirikan, kemudian pihak yang datang belakangan dengan jalan membeli saham yang dijual manajemen perseroan terbatas pada saat IPO atau di pasar perdana, dan pihak yang membeli saham dari pihak lain di pasar sekunder. Dengan demikian di dalam perseroan terbatas tidak terdapat dua pihak atau lebih yang melakukan akad serta ijab dan qabul tetapi yang ada berupa pembelian saham oleh siapa saja sebagai kehendak pribadinya yang bersifat sepihak. Artinya untuk menjadi rekanan/patner bagi seseorang dalam suatu perseroan terbatas maka cukup baginya dengan membeli saham perseroan terbatas tersebut (an-Nabhani, 2000).

Jelaslah kebatilan dalam perseroan terbatas tersebut karena tidak memenuhi adanya akad serta ijab dan qabul yang disyaratkan dalam Islam. Mereka yang ikut serta dalam perseroan terbatas hanyalah rekanan dalam modal (syarikul mal) saja. ${ }^{1}$ Masalah perseroan terbatas inilah yang terlewatkan dalam pembahasan konsep dan aplikasi pasar modal syariah.

\section{Transaksi Saham: Prespektif Syariah}

Karena perseroan terbatas merupakan suatu bentuk perseroan yang batil, maka saham yang diterbitkan perseroan terbatas dengan tujuan menambah modal dan diperdagangkan dalam pasar modal menjadi batil pula. 
Adapun pembahasan pembelian saham di pasar modal syariah harus dilakukan dengan tujuan berinvestasi bukan berspekulasi, artinya seseorang atau suatu badan usaha yang membeli saham berniat melakukan investasi jangka panjang, di mana fokus keuntungan yang ingin dia peroleh hanya dari pembagian deviden dan keikutsertaannya dalam perseroan terbatas dengan hak suara yang dimilikinya, maka itupun tidak menghilangkan kebatilan dalam pasar modal syariah. Karena apa yang dia lakukan dengan membeli saham tersebut sehingga berdasarkan hukum yang berlaku di negara yang bersangkutan dia memiliki hak milik terhadap suatu perseroan terbatas atau sebagai bagian dari orang yang turut andil dalam perseroan terbatas, namun tidak memenuhi syarat sah seseorang yang bergabung dalam suatu perseroan menurut hukum syara'.

Apalagi dalam prakteknya jual beli saham di pasar modal syariah sekalipun sangat sulit untuk menghindarkan dari kegiatan spekulasi, maksudnya sesuatu hal yang sulit untuk dicapai jika semua transaksi dalam pasar modal syariah didasarkan pada investasi jangka panjang. Karena perdagangan reguler yang dominan dalam pasar modal syariah bukan di pasar perdana tetapi di pasar sekunder. Di pasar sekunder inilah sangat terbuka bagi setiap pihak untuk ambil untung dengan melakukan transaksi jangka pendek dan di sinilah biasanya terjadi spekulasi.

Seandainya seluruh perdagangan saham baik di pasar primer maupun di pasar sekunder dilakukan atas dasar investasi maka kecepatan transaksi dan nilai kapitalisasi saham yang diperdagangkan akan sangat jauh berbeda dengan apa yang terjadi di pasar modal konvensional selama ini. Dengan asumsi ini maka dalam kacamata ekonomi sekarang pasar modal yang seperti itu tidak akan menarik minat banyak orang. Karena perdagangan saham terjadi dengan sangat lambat. Para investor yang ingin masuk dalam suatu perseroan harus menunggu suatu perseroan terbatas yang diminatinya menjual sahamnya di pasar perdana. Kemudian di pasar sekunder para investor harus menunggu dengan lama pihak pemegang saham suatu perseroan terbatas melepaskan sahamnya di lantai bursa.

Permasalahan muncul lagi dari emiten yang sahamnya diperdagangkan di pasar modal syariah. Meskipun pengelola pasar modal syariah sudah membersihkan emiten mana saja yang berhak masuk dalam pasar modal syariah melalui seleksi ketat. Akan tetapi ada satu yang bolong dari proses seleksi tersebut, yakni pembatasan suatu emiten tidak boleh terlibat transaksi dan utang piutang ribawi dalam batas-batas maksimal tertentu. Biasanya batasan aset yang mengandung riba 
adalah 30\% dari total aset emiten. Muncul pertanyaan apakah terjamin aset suatu emiten yang mengandung unsur riba tidak lebih dari 30\%.

Di sini permasalahannya bukan pada berapa persentasi unsur ribawi, sebab sedikit atau banyak yang namanya riba tetap haram. Dengan demikian saham yang diterbitkan dan diperdagangakan dari suatu emiten yang terlibat unsur ribawi menjadi haram. Sebab terjadi percampuran antara modal yang halal dengan modal yang haram, sehingga tidak bisa dipilah-pilah lagi mana modal murni dengan bunganya. Saat ini di Indonesia dan di belahan dunia lainnya, sangat sulit untuk menemukan suatu perseroan terbatas yang terbebas dari unsur-unsur ribawi.

\section{KESIMPULAN}

Dari paparan dan analisa di atas, dapat disimpulkan bahwa perbedaan pasar modal syariah dengan pasar modal konvensional dapat dilihat pada instrumen dan mekanisme transaksinya. Sedangkan perbedaan indeks saham Islam dengan indeks saham konvensional terletak pada kriteria saham emiten yang harus memenuhi prinsip-prinsip syariah. Penerbitan indeks saham Islam ini dapat dilakukan oleh pasar modal syariah dan pasar modal konvensional.

Hanya saja secara menyeluruh konsep pasar modal syariah dengan pasar modal konvensional tidak jauh berbeda. Karena instrumen utama yang diperdagangkan dalam pasar modal syariah dan pasar modal konvensional adalah saham. Meskipun dalam pasar modal syariah emiten yang sahamnya diperdagangkan harus bergerak pada sektor yang tidak bertentangan dengan Islam, tetapi hal tersebut tidak membedakan zat dan sifat saham dalam pasar modal konvensional.

Selanjutnya mengenai penilaian terhadap konsep pasar modal syariah itu sendiri, yakni yang berkaitan dengan saham sebagai instrumen utama di dalam pasar modal syariah, maka syara' tidak membolehkan perdagangan saham. Begitu pula menerbitkan saham dengan tujuan menambah permodalan perusahaan, membeli saham dengan tujuan investasi dan memperdagangkannya untuk mengambil keuntungan (capital gain) dari selisih harga (margin) merupakan kegiatan batil dalam Islam.

Menyangkut permasalahan di atas, penulis mengusulkan hal-hal berikut: 
Pertama, penulis sepakat bahwa suatu perusahaan yang memerlukan modal harus bergerak pada sektor yang tidak bertentangan dengan Islam dan tidak terkait dengan riba.

Kedua, untuk melakukan investasi pada suatu perusahaan, seorang investor muslim harus memilih perusahaan-perusahaan yang bentuknya memenuhi kriteria Islam seperti syirkah inan, abdan, mudharabah, wujuh dan mufawadhah.

Memang bentuk-bentuk syirkah Islam tersebut kurang dikenal dalam masyarakat dan peraturannya di Indonesia belum ada. Karena itu pasar modal syariah harus mengembangkan dan mensosialisasikan bentuk-bentuk syirkah Islam ke masyarakat, serta bersama masyarakat mendesak pemerintah mengeluarkan peraturan yang mengayomi syirkah Islam, bukannya merubah sebagian konsep pasar modal konvensional saja sehingga kesan yang didapat penulis pada pasar modal syariah selama ini adalah labelisasi Islam pada lembaga perekonomian Kapitalis yang telah eksis.

Ketiga, sarana-sarana investasi yang dikembangkan dalam pasar modal syariah haruslah yang telah memenuhi kriteria Islam dan mengikuti/disesuaikan dengan bentuk-bentuk syirkah Islam, sehingga nantinya tidak terdapat keraguan sedikitpun pada pasar modal syariah.

Dengan mengembangkan pola di atas, diharapkan pasar modal syariah benar-benar merupakan tempat pertemuan antara orang-orang yang membutuhkan modal dengan para investor yang ingin menanamkan modalnya di sektor produktif, sehingga kedua-duanya dapat melakukan kerja sama ataupun sama-sama meleburkan diri dalam suatu syirkah Islam dalam mengelola dan mengembangkan harta. 


\section{DAFTAR PUSTAKA}

Al-Amine, Muhammad al-Bashir Muhammad. 2001, The Islamic Bonds Market: Posibilities and Challenges, International Journal of Islamic Financial Services, Volume 3, No.1, April-June, http://islamicfinance.net/ journals/journa19/albashir.pdf.

Alhabshi, Syed Othman, Towards an Islamic Capital Market, http://vlib.unitarkli1.edu.my/staff-publications/datuk/Nst19feb93.pdf.

Ali Ahmad Salus, 1998, al-Iqtishad al-Islami wa al-Qadloya al-Mu'ashirah, Vol. I, (Bilbis: Dar al-Taqwa li an-Nasyr wa al-Tauzi'.

An-Nabhani, Taqyuddin. 2000, Membangun Sistem Ekonomi Alternatif; Perspektif Islam, Surabaya: Risalah Gusti.

Anoraga, Pandji dan Pakarti, Piji. 2001, Pengantar Pasar Modal, Jakarta: PT Rineka Cipta.

Anwar, Farial. 2002, Wall Street, BEJ, dan Rupiah, Republika Online 29 Juli.

Bapepam, Annual Report Bapepam 2002, http://www.bapepam.go.id/profil/ annual/index.htm

Beik, Irfan Syauqi. 2003, Prinsip Pasar Modal Syariah, Republika Online 21 Maret.

Danareksa.Com. 2003, 236 Saham Emiten di BEJ Sesuai Syariah, 21 April.

Danareksa.Com. 2002, Reksa Dana Syariah, Bagi yang Anti Riba, 6 Mei.

Dow Jones, Overview Islamic Market Indexes, http://www.djindexes.com/ jsp/islamicMarket.jsp?sideMenu=true. Dan http://www.djindexes.com/ jsp/islamicMarketOverView.jsp.

FTSE. 2001, Ground Rules for the Management of the FTSE Global Islamic Index Series, Calculated in Association with the International Investor, Version 2.3 October, http://webserver2.ftse.com/ground-rules/pdfs/global-islamic-groundrules.pdf.

Gunawan, Muhammad. 2002, Bagaimana Seharusnya Obligasi Syariah, Republika Online 7 Oktober. 
Hakim, Sam dan Rashidian, Manochehr, Risk \& Return of Islamic Stock Market Indexes, http://www.erf.org.eg/9thannualconf/9thPDFPresented /Finance/F-P Sam Rashidian.pdf.

Jakarta Stock Exchange, Indeks Harga Saham, www.jsx.co.id

Jakarta Stock Exchange, Mengenal Pasar Modal, www.jsx.co.id

Noer, U. Saefudin. 2003, Peluang Investasi Obligasi Syariah, Republika Online 7 Juli.

Obaidullah, Mohammed. 2001, Ethics and Efficiency in Islamic Stock Market, International Journal of Islamic Financial Services, Volume 3, No.2, July September.

Priyono, B. Herry, Bisnis Sesudah Neoliberalisme, Kompas Cyber Media, http://www.kompas.com/kompas-cetak/0209/18/opini/bisn04.htm

Republika Online. 2003, Batasa Luncurkan Reksadana Syariah, 24 Juli.

Republika Online. 2003, Pasar Modal Syariah Resmi Diluncurkan, 15 Maret.

Republika Online. 2003, Reksa Dana Syariah Belum Menggembirakan, 18 Maret.

Samuelson, Paul A. dan Nordhaus, William P.. 1997, Makroekonomi Edisi Keempatbelas, Jakarta: Penerbit Erlangga.

Singh, Kavaljit. 1998, Memahami Globalisasi Keuangan: Panduan untuk Memperkuat Rakyat, Jakarta: YAKOMA-PGI.

Woods, Alan dan Grant, Ted. 1999, Di Atas Mata Pisau, Perspektifbagi Ekonomi Dunia, www.marxist.com 